\title{
Chokeberry Anthocyanin Extract as Pancreatic $\beta$-Cell Protectors in Two Models of Induced Oxidative Stress
}

\author{
Dumitriţa Rugină, ${ }^{1}$ Zoriţa Diaconeasa, ${ }^{2}$ Cristina Coman, ${ }^{2}$ Andrea Bunea, ${ }^{3}$ \\ Carmen Socaciu, ${ }^{2}$ and Adela Pintea ${ }^{1}$ \\ ${ }^{1}$ Faculty of Veterinary Medicine, University of Agricultural Sciences and Veterinary Medicine, Mănăştur 3-5, \\ 400372 Cluj-Napoca, Romania \\ ${ }^{2}$ Faculty of Food Science and Technology, University of Agricultural Sciences and Veterinary Medicine, Mănăștur 3-5, \\ 400372 Cluj-Napoca, Romania \\ ${ }^{3}$ Faculty of Animals Breeds and Biotechnology, University of Agricultural Sciences and Veterinary Medicine, \\ Mănăştur 3-5, 400372 Cluj-Napoca, Romania
}

Correspondence should be addressed to Adela Pintea; apintea@usamvcluj.ro

Received 30 December 2014; Revised 29 April 2015; Accepted 3 May 2015

Academic Editor: Cinzia Signorini

Copyright (C) 2015 Dumitriţa Rugină et al. This is an open access article distributed under the Creative Commons Attribution License, which permits unrestricted use, distribution, and reproduction in any medium, provided the original work is properly cited.

\begin{abstract}
The aim of this study was to investigate the protective effects of a chokeberry anthocyanin extract (CAE) on pancreatic $\beta$-cells ( $\beta$ TC3) exposed to hydrogen peroxide- $\left(\mathrm{H}_{2} \mathrm{O}_{2}-\right)$ and high glucose- (HG-) induced oxidative stress conditions. In order to quantify individual anthocyanins high performance liquid chromatography (HPLC) coupled to photodiode array (PDA) was used. The identification of the fragment ion pattern of anthocyanins was carried out by electrospray ionization mass spectrometry (LC-ESIMS). The results showed that physiologically achievable concentrations of CAE $(1,5$, and $10 \mu \mathrm{M})$ protect $\beta$ TC 3 against $\mathrm{H}_{2} \mathrm{O}_{2}$ - and HG-induced cytotoxicity. Antioxidant enzymes such as superoxide dismutase (SOD), catalase (CAT), and glutathione peroxidase $(\mathrm{GPx})$ were increased in pancreatic $\beta$-cells pretreated with CAE compared to cells exposed to the prooxidant agents. GSH levels initially reduced after exposure to $\mathrm{H}_{2} \mathrm{O}_{2}$ and $\mathrm{HG}$ were restored by pretreatment with CAE. Insulin secretion in $\beta$ TC 3 cells was enhanced by CAE pretreatment. CAE restored the insulin pool and diminished the intracellular reactive oxygen species level in glucose-induced stress condition in $\beta$ TC3 cells. These results demonstrate that anthocyanins from CAE were biologically active, showing a secretagogue potential and an antioxidative protection of enzymatic systems, conferring protection against $\mathrm{H}_{2} \mathrm{O}_{2}$ and glucose toxicity in $\beta$ TC3 cells.
\end{abstract}

\section{Introduction}

In type 2 diabetes mellitus a chronic exposure of $\beta \mathrm{TC} 3$ cells to HG levels leads to their irreversible failure causing glucose toxicity via increased oxidative stress [1]. Oxidative stress can be defined as an imbalance between the antioxidant defense system and the production of reactive oxygen species such as superoxide anion, hydroxyl radical, and hydrogen peroxide. Disturbances of the antioxidant defense system in diabetes involve the alteration of antioxidant enzymes [2] and impaired glutathione metabolism [3]. A promising strategy is to prevent oxidative stress imbalance by natural products with antioxidant potential that may act as free radical scavengers in pancreatic $\beta$-cells. Some of the previously reported studies investigating the use of different plants, plant extracts, or bioactive natural compounds as potential antidiabetics were reviewed in a recent publication [4].

Anthocyanins are polyphenolic compounds which have been shown to exhibit pharmacological properties, such as anti-inflammatory, antitumor, and antioxidant activities [5, 6]. Long-term administration of berry-derived supplements, including anthocyanins, could inhibit the development of the early stages of some diabetic complications [7]. There are a number of in vitro studies reporting the anthocyanins 
protecting effect on pancreatic $\beta$-cells $[6,8,9]$. Anthocyanins from Chinese bayberry extract were found to protect pancreatic $\beta$-cells INS-1 against induced necrosis and apoptosis, via ERK1/2- and PI3K/Akt-mediated heme oxygenase-1 upregulation [6]. Jayaprakasam et al. (2005) demonstrated the ability of cyanidin-3-O-glucoside and delphinidin-3-O-glucoside to stimulate the insulin secretion from rodent pancreatic $\beta$ cells [8]. Using multiple cell-based bioassays, the potentially antidiabetic effects and the insulin-like activity of Vaccinium angustifolium were demonstrated [9]. There are some experiments on streptozotocin-induced diabetic rat model that reported the antioxidative and hypoglycemic properties of the chokeberry fruit extract $[10,11]$.

Anthocyanins are absorbed in blood in an intact form, so they can reach various tissues and can modulate metabolic changes in the body $[12,13]$. After an anthocyanin intake, their concentrations found in plasma were very low [14]. Some pharmacokinetic data suggested that the concentrations of anthocyanins in plasma of rats were around $2 \mu \mathrm{mol} / \mathrm{L}$, after a diet enriched in chokeberry, bilberry, and grape, as equivalent of $3.85 \mathrm{~g}$ cyanidin-3-O-galactoside $/ \mathrm{kg}$, administered for 14 weeks [15]. Regarding the bioavailability of chokeberry anthocyanins, it was reported that their plasma concentrations in humans after consuming a chokeberry extract were $591 \mathrm{nmol} / \mathrm{L}$. These concentrations were reached in about $2 \mathrm{~h}$ after consumption [16]. The total concentration of anthocyanins in human plasma after chokeberry juice consumption was about $32.7 \mathrm{nmol} / \mathrm{L}$ and was reached in about $1.3 \mathrm{~h}$ [17].

The present study was designed to prove the protecting role of a chokeberry enriched anthocyanin fraction upon pancreatic $\beta$-cells, using two models of oxidative-induced stress. The physiologically achievable concentrations of CAE $(1,5$, and $10 \mu \mathrm{M})$ were administered to $\beta \mathrm{TC} 3$ for $24 \mathrm{~h}$. The CAE behavior towards the antioxidant defense system (SOD, CAT, GPx, and GSH), the insulin secretion, and the intracellular reactive oxygen species (ROS) was assessed in $\mathrm{H}_{2} \mathrm{O}_{2}$ - and $\mathrm{HG}$-induced stress conditions in $\beta$ TC 3 cells.

\section{Materials and Methods}

2.1. Reagents. The standard compounds, including cyanidin3-O-galactoside (90\% purity), cyanidin-3-O-glucoside $(95 \%$ purity), cyanidin (95\% purity), 6-hydroxy-2,5,7,8-tetramethylchroman-2-carboxylic acid (Trolox) (98\% purity), 2,2-azinobis(3-ethylbenzothiazoline-6-sulfonic acid) diammonium salt (ABTS) (98\% purity), 2,9-dimethyl-1,10-phenanthroline (Neocuproine) (99\% purity), potassium persulfate (99\% purity), acetonitrile, formic acid, ethanol, methanol, and dimethyl sulfoxide (DMSO), were obtained from SigmaAldrich (Darmstadt, Germany). Cyanidin-3-O-galactoside and cyanidin-3-O-arabinoside standards were bought from Polyphenols (Sandnes, Norway). $\mathrm{HCl}, \mathrm{NaNO}_{2}, \mathrm{H}_{2} \mathrm{O}_{2}$, and $\mathrm{CuCl}_{2}$ were purchased from Merck (Darmstadt, Germany). Fetal bovine serum (FBS), Lonza, Dulbecco's Modified Eagle Medium (DMEM), and 3-(4,5-dimethylthiazol-2-yl)-2,5diphenyltetrazolium bromide (MTT) were purchased from Lonza Group Ltd. (Basel, Switzerland). Glutamine, penicillin and streptomycin, and amphotericin were purchased from
Sigma Chemical Co. (St. Louis, MO). The water used for experiments was treated in a Milli-Q water purification system.

2.2. Extraction of Anthocyanins and Nonanthocyanins Phenolics. The fruits of Aronia melanocarpa Nero cultivar were collected in the middle of August at a plantation near ClujNapoca (Romania) and preserved at $-20^{\circ} \mathrm{C}$, immediately after harvest. Anthocyanin and nonanthocyanin compounds were extracted by homogenization of chokeberries $(5 \mathrm{~g})$ in methanol containing $\mathrm{HCl}(0.3 \%)$ using a homogenizer (Miccra D-9 KT Digitronic, Germany) and then concentrated at $35^{\circ} \mathrm{C}$ under reduced pressure (Rotavapor R-124, Buchi, Switzerland). Afterwards, the extract was fractioned following the procedure described by [18]. Briefly, the aqueous extract $(50 \mu \mathrm{L})$ was filtered through a C-18 Sep-Pak cartridge (sorbent mass $=50 \mathrm{mg}$ ) (Waters Corp., Milford, MA), previously activated with methanol followed by $0.01 \%$ aqueous $\mathrm{HCl}$. Anthocyanins and other polyphenolics were adsorbed onto the column while sugars, acids, and other water-soluble compounds were removed by washing with 2 volumes of $0.01 \%$ aqueous $\mathrm{HCl}$. The second fraction, containing polyphenols (other than anthocyanins), was subsequently eluted with 2 volumes of ethyl acetate. And a third fraction, enriched in anthocyanins, was eluted with 4 volumes of methanol containing $0.01 \% \mathrm{HCl}$. This last fraction, named $\mathrm{CAE}$, was evaporated by a rotatory evaporator under vacuum, at $35^{\circ} \mathrm{C}$.

2.3. HPLC-ESI-MS Analysis of Anthocyanins. Analyses were performed on an Agilent Technologies 1200 HPLC system (Chelmsford, MA, USA) equipped with G1311A Quaternary Pump, G1322A degasser, G1329A autosampler, and G1315D photodiode array (PDA) detector and a Luna Phenomenex C18 column $(5 \mu \mathrm{m}, 25 \mathrm{~cm} \times 4.6 \mathrm{~mm})$ was used. In-line MS data were recorded by directing the LC flow to a Quadrupole 6110 mass spectrometer (Agilent Technologies, Chelmsford, MA) equipped with an ESI probe. Most settings were optimized using Flow Injection Analysis (FIA) (Agilent ChemStation) via automatic tuning with cyanidin-3-O-galactoside in positive ion mode. The mobile phase consisted in solvent $\mathrm{A}$, formic acid (4.5\%) in bidistilled water, and solvent B, acetonitrile. The gradient elution system was $10 \% \mathrm{~B}, 0-9 \mathrm{~min} ; 12 \%$ B, $10-17 \mathrm{~min} ; 25 \% \mathrm{~B}, 18-30 \mathrm{~min} ; 10 \% \mathrm{~B}, 31-35 \mathrm{~min}$. The flow rate was $0.8 \mathrm{~mL} / \mathrm{min}$ and the analyses were performed at $35^{\circ} \mathrm{C}$ temperature. The anthocyanins elution order was monitored at $520 \mathrm{~nm}$ wavelength. For the mass spectrometry (MS) analysis, the positive ion mode scanning $\left(\mathrm{ESI}^{+}\right)$and fragmentation system, from $m / z 260$ to 1000 , were used. The measurements were performed in the positive mode with an ion spray voltage of $3000 \mathrm{~V}$, fragmentor of $70 \mathrm{eV}$ and $130 \mathrm{eV}$, drying gas temperature of $350^{\circ} \mathrm{C}$, gas flow $(\mathrm{N} 2)$ of $8 \mathrm{~L} / \mathrm{min}$, and nebulizer pressure of $40 \mathrm{psi}$. The anthocyanin quantification was performed by using cyanidin-3-O-galactoside as pure standard and the weight correction factors. The weight correction factors were calculated as the ratio between molecular weights of the each quantified anthocyanin and the molecular weight of cyanidin 3-O-galactoside. 


\subsection{Antioxidant Activity}

2.4.1. Cupric Reducing Antioxidant Potential (CUPRAC) Assay and Scavenging Effect on ABTS Radical. The cupric ion reducing antioxidant potential of CAE was determined according to a method reported before [19]. The scavenging ability of chokeberry extracts against radical anion $\mathrm{ABTS}^{\circ+}$ was determined according to the procedure described by Arnao et al. (2001) [20]. The absorbances were recorded using a spectrophotometer (JASCO V-630 series, International Co., Ltd., Japan) against the blank reagent. The standard curve was prepared using different concentrations of Trolox and the results were expressed as $\mu \mathrm{mol} \mathrm{TE} / \mathrm{g} \mathrm{FW}$.

2.5. Cell Culture and Proliferation. The mouse pancreatic $\beta$ cell line TC3 was maintained in Dulbecco's Modified Eagle Medium (DMEM) containing $5 \mathrm{mM}$ glucose supplemented with $10 \%$ fetal bovine serum, $4 \mathrm{mM}$ glutamine, $1 \%$ penicillin and streptomycin at $37^{\circ} \mathrm{C}, 5 \% \mathrm{CO}_{2}$, and $95 \%$ relative humidity. The pancreatic $\beta$-cells were plated $\left(1 \times 10^{4}\right.$ cells/well $)$ for $24 \mathrm{~h}$ in 96-well microplates. CAE concentrations of 1,5 , and $10 \mu \mathrm{M} \mathrm{Cy}$-3-gal equivalents were used as treatment in pancreatic $\beta$-cells for $24 \mathrm{~h}$. Stress conditions were induced by HG (50 and $100 \mathrm{mM})$ administered for $24 \mathrm{~h}$ or $\mathrm{H}_{2} \mathrm{O}_{2}(70 \mu \mathrm{M})$ administered for $30 \mathrm{~min}$, prior to each assay. The stock solution of CAE $(395 \mu \mathrm{g} / \mathrm{mL})$ was prepared in deionized sterile water and further filtered through a $0.22 \mu \mathrm{m}$ Millipore filter.

The number of viable cells was determined with the 3(4,5-dimethylthiazol-2-yl)-2,5-diphenyltetrazolium bromide (MTT) cell proliferation reagent. This method uses the property of viable cells to reduce MTT reagent into a colored formazan. Cells were washed with PBS and incubated with MTT solution $(0.5 \mathrm{mg} / \mathrm{mL})$ for $1 \mathrm{~h}$. The absorbances of formazan solubilized by DMSO were read at $550 \mathrm{~nm}$, respectively, at $630 \mathrm{~nm}$ (for background) using the microplate plate reader HT BioTek Synergy (BioTek Instruments, USA).

2.6. Antioxidant Enzymes Activity and Reduced Glutathione. $\beta$ TC 3 cells $\left(5 \times 10^{5}\right.$ cells/well $)$ were seeded on 6 -well plates and cultured in complete medium for $24 \mathrm{~h}$. The medium was then replaced with complete medium containing or not containing CAE at various concentrations $(1,5$, and $10 \mu \mathrm{M}$ Cy-3-gal) in presence or absence of the prooxidant agents $\mathrm{H}_{2} \mathrm{O}_{2}$ and HG. After completing the treatment, cell extracts were prepared according to manufacturer's instruction and for each parameter the protein content was determined by the bicinchoninic acid assay (Sigma, St. Louis, USA). For all antioxidant enzymes, the activity was expressed on mg protein. Catalase (CAT), glutathione peroxidase (GPx), superoxide dismutase (SOD) activities, and glutathione reduced (GSH) were performed according to instruction assay kits (Cayman Chemical Company, Michigan, USA).

2.7. Intracellular Reactive Species Assay. Intracellular reactive oxygen species (ROS) assay is based on the oxidation of $2^{\prime}, 7^{\prime}$-dichlorodihydrofluorescein (DCHF) by intracellular peroxides, forming the $2^{\prime}, 7^{\prime}$-dichlorofluorescein (DCF). Fluorescence of this compound was measured by a BioTek microplate reader, at the excitation $485 / 10 \mathrm{~nm}$ and the emission $528 / 20 \mathrm{~nm}$ at $37^{\circ} \mathrm{C}$, after $4 \mathrm{~h} \mathrm{[21].}$

2.8. Insulin Secretion. For the measurement of secreted insulin $\beta$ TC3 cells $\left(5 \times 10^{5}\right.$ cells/well $)$ were seeded on a 6-well plate and treated according to the protocol presented above. Before performing the assay the culture medium was removed and replaced with Krebs-Ringer buffer (KRB; $129 \mathrm{mM} \mathrm{NaCl}, 4.8 \mathrm{mM} \mathrm{KCl}, 1.2 \mathrm{mM} \mathrm{MgSO}_{4}, 1.2 \mathrm{mM}$ $\mathrm{KH}_{2} \mathrm{PO}_{4}, 2.5 \mathrm{mM} \mathrm{CaCl} 2,5 \mathrm{mM} \mathrm{NaHCO}, 10 \mathrm{mM}$ HEPES, and $0.1 \% \mathrm{BSA}$ ) containing $2.5 \mathrm{mM}$ glucose and $2 \%$ FBS for $30 \mathrm{~min}$ at $37^{\circ} \mathrm{C}$ and then it was collected from each well and subjected to insulin secretion measurement according to manufacturer's instructions (Mercodia Ultrasensitive Mouse Insulin ELISA, Uppsala, Sweden).

2.9. Statistical Analysis. Statistical analysis was performed using the Dunnett multiple comparison test of GraphPad Prism version 5.00. Registered data represented the mean values and standard deviations (SD) of three experiments, considering three levels of significance $(*$ meant significant $P<0.05, * *$ meant very significant $P<0.01$, and $* * *$ meant extremely significant $P<0.001$ ). Figure 2 was elaborated using Chemdraw Ultra 13 software.

\section{Results and Discussion}

3.1. Quantitative Analysis of Individual Anthocyanin Components from CAE, as Determined by HPLC-DAD-ESI-MS. Anthocyanins identification and peak assignment were based on their retention times compared with pure standards, MS data, and published information. As can be seen in Figure 1, by HPLC-PDA analysis recorded at $520 \mathrm{~nm}$, four peaks were identified. By HPLC-MS, each peak was identified, namely, cyanidin-3-O-galactoside (1) with $m / z=449$, cyanidin-3-Oglucoside (2) with $m / z=449$, cyanidin-3-O-arabinoside (3) with $m / z=419$, and cyanidin-3-O-xyloside (4), with $m / z=$ 419. The ESI-MS profiles of these compounds present specific molecular ions $\mathrm{M}^{+}$and the fragment resulting from the loss of the sugar molecule $287 \mathrm{~m} / z$ corresponds to the molecular ion of cyanidin aglycone. The total anthocyanin content was $1319.18 \mathrm{mg} / 100 \mathrm{~g}$ FW (Table 1). Cyanidin-3-O-galactoside was found to be the major anthocyanin present in the CAE accounting around $69 \%$ of all anthocyanins. Similar amounts of total anthocyanins were reported for chokeberries by other authors, $1478.1 \mathrm{mg} / 100 \mathrm{~g} \mathrm{FW}$ [22], $1958 \mathrm{mg} / 100 \mathrm{~g}$ DW [23].

3.2. Antioxidant Activity of CAE. Two Single Electron Transfer (SET) based assays ABTS and CUPRAC were used to measure the potential of antioxidants to reduce an oxidant.

The ABTS assay uses $\mathrm{K}_{2} \mathrm{~S}_{2} \mathrm{O}_{8}$ as oxidant and measures the antioxidants ability to scavenge the $\mathrm{ABTS}^{+\bullet}$ radical. In our previous study three different Aronia sp. cultivars were evaluated for their ex vivo antioxidant activity and their potential to scavenge $\mathrm{ABTS}^{+\bullet}$ and showed values between 95 and $170 \mu \mathrm{mol}$ TE/g FW [24]. However Aronia melanocarpa Nero cultivar used in these experiments showed a higher radical scavenging potential of $180 \mu \mathrm{mol} \mathrm{TE} / \mathrm{g} \mathrm{FW}$ (Table 1). The values obtained for the scavenging activity toward $\mathrm{ABTS}^{+}$ 
TABLE 1: The CAE anthocyanin content (mg/100 g FW) and the antioxidant potential ( $\mu \mathrm{mol} \mathrm{TE} / \mathrm{g} \mathrm{FW}$ ).

\begin{tabular}{|c|c|c|c|c|}
\hline \multirow{2}{*}{ Anthocyanins } & \multicolumn{2}{|c|}{ Anthocyanin content } & \multirow[t]{2}{*}{ ABTS } & \multirow[t]{2}{*}{ CUPRAC } \\
\hline & $\mathrm{mg} / 100 \mathrm{~g}$ & $\%$ & & \\
\hline Сy-3-O-galactoside & $906.9 \pm 20$ & 69.00 & & \\
\hline Cy-3-O-glucoside & $14.9 \pm 30$ & 1.10 & & \\
\hline Сy-3-O-arabinoside & $352.4 \pm 15$ & 27.00 & $180.50 \pm 8.10$ & $203.80 \pm 8.70$ \\
\hline Cy-3-O-xyloside & $44.8 \pm 80$ & 3.40 & & \\
\hline Total & 1319.18 & 100.00 & & \\
\hline
\end{tabular}

Cy: cyanidin.

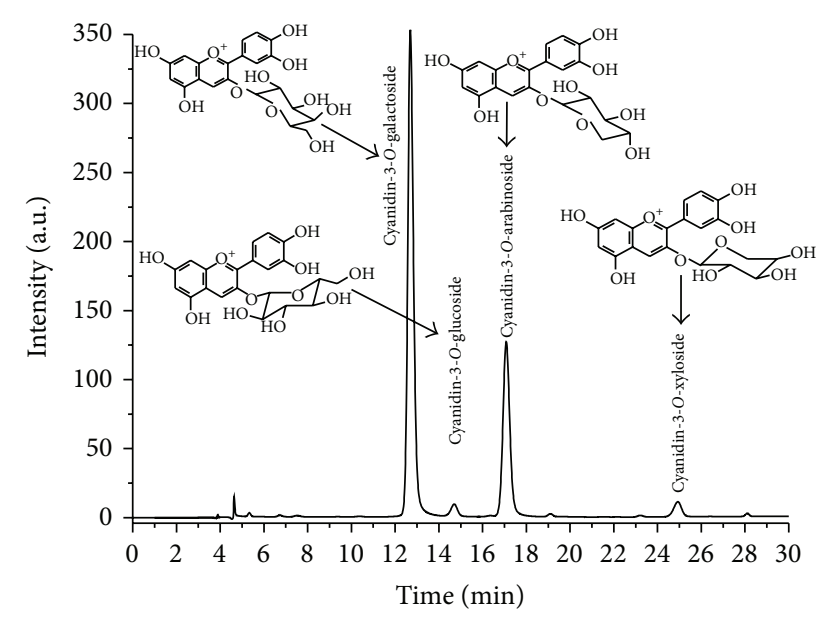

FIGURE 1: HPLC chromatogram of chokeberry anthocyanin-rich fraction (CAE). The HPLC-PDA chromatogram was registered at the wavelength of $520 \mathrm{~nm}$. The chromatogram revealed that peaks correspond to the four anthocyanins, as nominated in the figure.

radical are similar to those reported in a recent study, that is, $37.44 \mathrm{mg}$ TE/g sample [25]. Considering the water content of berries to be around $85 \%$ [26], our data are in the same concentrations range with the scavenging effect expressed, 439.4 $\mu \mathrm{M}$ Trolox/100 g dry weight [23].

The CUPRAC assay is carried out at $\mathrm{pH} 7.0$, close to physiological $\mathrm{pH}$, and the reaction assay involves fast kinetics [27]. The ability of CAE to reduce cupric ion $\left(\mathrm{Cu}^{2+}\right)$, as shown in Table 1, was determined to be $200 \mu \mathrm{mol} \mathrm{TE} / \mathrm{g}$ FW. In a previous study we obtained for other chokeberry cultivars values from 150 to $232 \mu \mathrm{mol} \mathrm{TE} / \mathrm{g}$ FW [24]. Recently Sariburun et al. (2010) reported CUPRAC values ranging between 47.1 and $127.9 \mu \mathrm{mol} \mathrm{TE} / \mathrm{g}$ FW for some raspberry and blackberry cultivars [28]. To the best of our knowledge, there is no literature data about cupric reducing antioxidant potential of similar chokeberry anthocyanin-rich extracts.

3.3. Pancreatic $\beta$-Cell Proliferation after CAE Treatment in Oxidative Stress-Induced Conditions. In order to elucidate the protective effects of CAE in the presence of the prooxidant agents, $\mathrm{HG}$ and $\mathrm{H}_{2} \mathrm{O}_{2}$, we first assessed the cell proliferation. The working $\mathrm{H}_{2} \mathrm{O}_{2}$ concentration was chosen from a survey curve of $\beta$ TC3 cells treated with different $\mathrm{H}_{2} \mathrm{O}_{2}$ concentrations ranging from 0 to $600 \mu \mathrm{M}$. The $\mathrm{IC}_{50}$ concentration of $70 \mu \mathrm{M}$ was used in this experiment as stressor agent for the $\beta$ TC3 cells. Other previously published articles on $\beta$ pancreatic cells have used $\mathrm{H}_{2} \mathrm{O}_{2}$ in the range $200-400 \mu \mathrm{M}$ $[29,30]$.

With respect to the glucose concentration used, some authors have reported concentrations between 5.6 and $30 \mathrm{mM}$ as oxidative stress inducer $[31,32]$. In a recent study, a high dose of glucose $(150 \mathrm{mM})$ was used as prooxidant agent due to a $\beta$-pancreatic MIN6 cell viability decreased by only $26 \%$ [33]. Our working concentrations of glucose were chosen after a preliminary assay, observing that the $\beta$-pancreatic TC3 cell viability after $24 \mathrm{~h}$ was reduced with only $20 \%$ by $50 \mathrm{mM}$ and with $34 \%$ by $100 \mathrm{mM}$ glucose in culture medium.

The CAE administration at physiological doses $(1,5$, and $10 \mu \mathrm{M}$ Cy-3-gal) increased the $\beta$-pancreatic TC3 cell proliferation with about $23 \%, 18 \%$, and $8 \%$, respectively, after $24 \mathrm{~h}$ of treatment. As shown in Figure 3, the CAE treatment in the presence of $50 \mathrm{mM}$ glucose slightly increased the cell viability. The treatment with low doses of CAE in the HGinduced oxidative stress using $100 \mathrm{mM}$ glucose enhanced the cell proliferation comparing to $100 \mathrm{mM}$ glucose controls without CAE (Figure 3). Meanwhile, CAE in the presence of $\mathrm{H}_{2} \mathrm{O}_{2}$ stress inducer stimulated the $\beta$-pancreatic TC3 cell proliferation. According to cell proliferation data it could be concluded that CAE had an proliferative potential on $\beta$ pancreatic TC3 cells in oxidative stress-induced conditions.

3.4. In Vitro Antioxidant Activity of Pancreatic $\beta$-Cells CAE Treated in Stress Conditions. The enzymatic antioxidants such as superoxide dismutase (SOD), catalase (CAT), and glutathione peroxidase $(\mathrm{GPx})$ and the nonenzymatic antioxidant (GSH) can act together to attenuate the ROS produced by $\mathrm{HG}$ and $\mathrm{H}_{2} \mathrm{O}_{2}$ administration to $\beta$-pancreatic cells. Cytosolic or mitochondrial forms of SOD catalyze the conversion of superoxide anion $\left(\mathrm{O}_{2}{ }^{--}\right)$to molecular oxygen $\left(\mathrm{O}_{2}\right)$ and hydrogen peroxide $\left(\mathrm{H}_{2} \mathrm{O}_{2}\right)$. This resulting $\mathrm{H}_{2} \mathrm{O}_{2}$ is then metabolized to harmless water and oxygen by CAT and GPx. SOD and CAT do not require any cofactors to function (Figure 2). Unlike SOD and CAT, GPx needs some cofactors (reduced glutathione, NADPH, and glucose 6-phosphate) and proteins (glutathione reductase and glucose-6-phosphate dehydrogenase) in order to operate effectively [34]. In consequence, ROS does not have a direct influence on GPx, but its function could be abolished due to a disorder in the glutathione system.

In the presence of $\mathrm{H}_{2} \mathrm{O}_{2}$ and $\mathrm{HG}$ as stress agents, the CAE induced a strong increase of CAT, GPx activities, and 


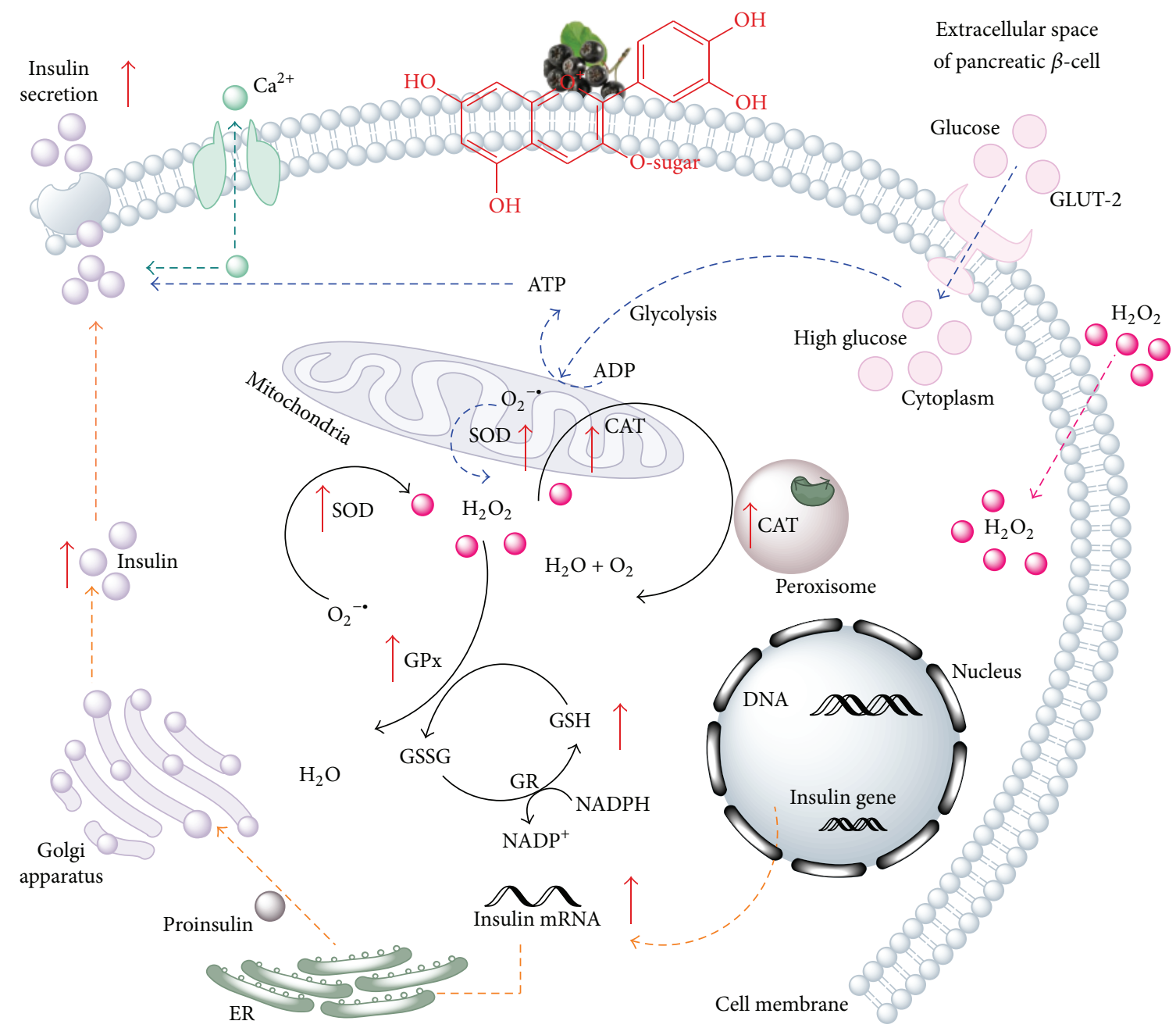

FIGURE 2: Schematic illustration of CAE-stimulated antioxidant enzyme and insulin secretion pathway in pancreatic $\beta$-cells in $\mathrm{HG}_{\text {and }} \mathrm{H}_{2} \mathrm{O}_{2}$ stress conditions. Glucose enters the cell across the plasma membrane through glucose transporters, like GLUT-2 for rodent $\beta$-cells. Once inside the cell the metabolic process of glucose called glycolysis begins. ATP is the end product of glycolysis. Further reactions take place in mitochondria where more ATP is produced. In connection with the electron transport chain the superoxide anion results. Cytosolic or mitochondrial forms of SOD catalyze the conversion of superoxide anion $\left(\mathrm{O}_{2}{ }^{--}\right)$to molecular oxygen $\left(\mathrm{O}_{2}\right)$ and hydrogen peroxide $\left(\mathrm{H}_{2} \mathrm{O}_{2}\right)$. Unlike glucose, $\mathrm{H}_{2} \mathrm{O}_{2}$ administered to cells diffuses through the cell membrane. The resulting $\mathrm{H}_{2} \mathrm{O}_{2}$ from glucose metabolism and the extracellular $\mathrm{H}_{2} \mathrm{O}_{2}$ are then metabolized to harmless water and oxygen by CAT and GPx. CAE increases the activity of SOD, CAT, and GPx, so the more active the metabolism of $\mathrm{H}_{2} \mathrm{O}_{2}$ is, the less the reactive species are formed in the cell. $\mathrm{GSH}$ levels are reduced by $\mathrm{H}_{2} \mathrm{O}_{2}$ and $\mathrm{HG}$ and restored by CAE. It is possible that the anthocyanins increase the insulin gene expression, because the CAE treatment attempts to restore the pool of insulin. Before being secreted out of the cell insulin is synthesized and converted to proinsulin in the endoplasmic reticulum (ER) folded and transported to the Golgi apparatus. Anthocyanins from CAE could also influence the opening of the voltage-gated $\mathrm{Ca}^{2+}$ channels, leading to an increased fusion of insulin granule with the cell membrane.

GSH content in $\beta$-pancreatic TC 3 cells, as shown in Figures $4(\mathrm{a})$ and 4 (b). Also, a slight increase in the activity of SOD was observed in CAE-treated $\beta$-pancreatic cells compared to untreated cells; see Figures 4(a)(A) and 4(b)(A). Since CAT and GPx have different enzymatic characteristic, both of them are $\mathrm{H}_{2} \mathrm{O}_{2}$-inactivating enzymes. $\mathrm{GPx}$ inactivates the $\mathrm{H}_{2} \mathrm{O}_{2}$ substrate with high affinity in a continuous rate of oxygen free radical production, whereas CAT has a lower affinity in a higher continuous rate of free ROS production [35]. A possible explanation for the statistically significant increased activities of CAT and GPx by CAE treatment in oxidative stress-induced conditions (50 mM HG and $70 \mu \mathrm{M} \mathrm{H}_{2} \mathrm{O}_{2}$ in $\beta$-pancreatic TC3 cells) could be the high rate production of their substrate $\mathrm{H}_{2} \mathrm{O}_{2}$ and a scarce existence of superoxide anion $\left(\mathrm{O}_{2}{ }^{--}\right)$(Figures $4(\mathrm{a})(\mathrm{B})$ and $4(\mathrm{a})(\mathrm{C})$ ).

Hence, $\beta$-pancreatic cells could be an easy target for ROS, possibly because of their low expression of SOD, catalase, and GPx genes (as reviewed by Robertson et al. (2003)) [36]. Compared to the liver enzymatic system, pancreatic islets contain 1\% catalase, 2\% GPx, and 29\% SOD1 activities (reviewed in Ježek et al. work (2012)) [37]. However, our results show that the CAE is acting when a scavenging excess 


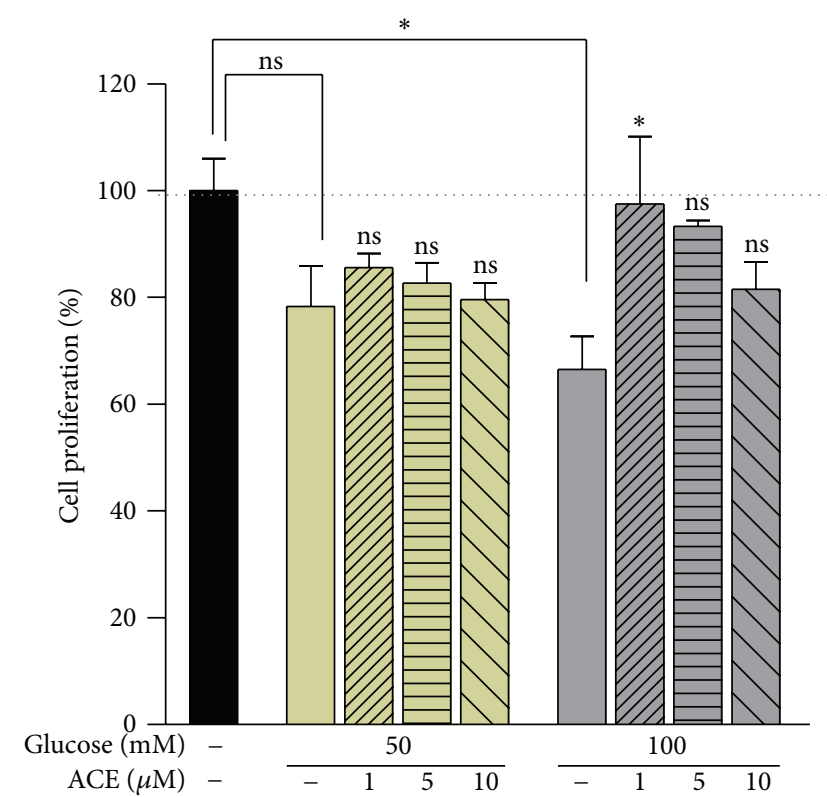

(a)

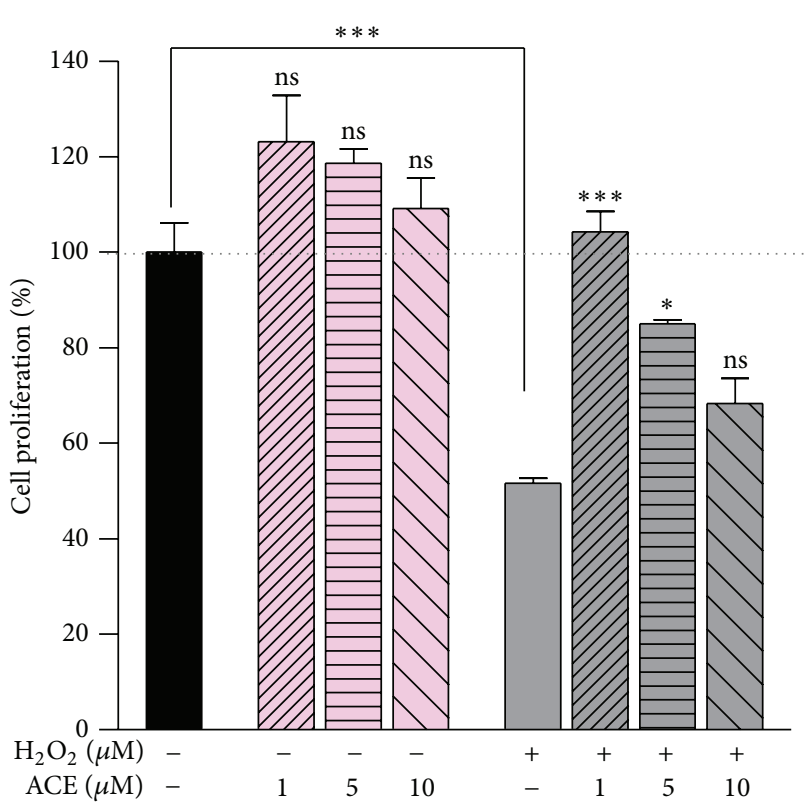

(b)

FIGURE 3: Cell viability assessed by MTT assay. CAE increases the proliferation of $\beta$ TC3 cells treated in (a) HG-induced stress for $24 \mathrm{~h}$ and (b) $\mathrm{H}_{2} \mathrm{O}_{2}$-induced stress for $15 \mathrm{~min}$. Data are expressed as mean $\pm \operatorname{SEM}(n=5)$. Statistically significant differences: ${ }^{*} P<0.05$, ${ }^{* *} P<0.01$, and ${ }^{* * *} P<0.001$ compared with control.

of free radicals was produced under induced stress conditions to ensure the $\beta$-pancreatic cells protection. Even though the enzymatic antioxidant defense system is considered to be poorly expressed in $\beta$-pancreatic cells, it can contribute to the "housekeeping" processes.

The efficiency of the chokeberry rich anthocyanin fraction towards SOD activity was demonstrated previously; the treatment induced an increased activity into rat blood unlike the control model. In the same study the GPx activity in the rat's blood was not affected after chokeberry extract administration [11]. The effect of other anthocyanins like pelargonidin restored the levels of SOD and CAT in diabetic rats after 2 weeks of treatment [38].

3.5. Insulin Secretion Activity of CAE in Pancreatic $\beta$-Cells Exposed to Stress Conditions. It has already been proved that the insulin secretion could be diminished by oxidative stress conditions $[39,40]$. Therefore, we investigated also the CAE insulin secretagogue effect in pancreatic $\beta$-cells exposed to $\mathrm{HG}$ and $\mathrm{H}_{2} \mathrm{O}_{2}$ stress conditions.

In our study the administration of CAE concentrations of 1,5 , and $10 \mu \mathrm{M}$ increased insulin secretion by 1,9 , and $18 \mathrm{ng}$ of insulin/mg of protein, respectively, under basal glucose condition (Figure $5(\mathrm{~b})(\mathrm{A}))$. The low dose of CAE $(1 \mu \mathrm{M})$ increased the insulin secretion by $4 \mathrm{ng}$ of insulin/mg of protein in HG (50 $\mathrm{mM}$ ) stress condition (Figure 5(a)(A)). In a dose-dependent manner the CAE administration attempted to restore the pool of insulin in the HG $(100 \mathrm{mM})$ environment (Figure 5(a)(A)). The CAE treatment in the presence of $\mathrm{H}_{2} \mathrm{O}_{2}$-induced stress did not have any influence on the secreted insulin in pancreatic $\beta$-cells (Figure 5(b)(A)). This may be possible if the insulin gene transcription was decreased after the exposure to $\mathrm{H}_{2} \mathrm{O}_{2}$ of pancreatic $\beta$-cells [41]. The insulin secretagogue effect of anthocyanins and anthocyanidins was demonstrated on pancreatic $\beta$-cells INS$1832 / 13$ previously [8]. In the same study an increment by the cyanidin-3-O-glucoside treatment of the insulin secretion was recorded, from $33 \mathrm{ng}$ insulin/mg protein to $46 \mathrm{ng}$ insulin/ $\mathrm{mg}$ protein in basal glucose $(4 \mathrm{mM})$ conditions. Glucoseinduced stress $(10 \mathrm{mM})$ increased for about 4 times the insulin secretion. It was observed that higher than $10 \mu \mathrm{g} / \mathrm{mL}$ $(20 \mu \mathrm{M})$ cyanidin-3-O-glucoside concentrations did not significantly improve the insulin secretion in rodent pancreatic $\beta$-cells INS-1 832/13 [8]. Some in vivo studies reported that cyanidin-3-O-glucoside and anthocyanin-rich extracts ameliorated the hyperglycemia and the insulin sensitivity in diabetic mice $[42,43]$. Insulin gene expression was decreased by exposure to oxidative stress in HIT-T15 cells or isolated rat islets [41].

3.6. Intracellular Reactive Species Level after CAE Administration in Pancreatic $\beta$-Cells in Oxidative Stress Conditions. It is shown that HG- and $\mathrm{H}_{2} \mathrm{O}_{2}$-induced stress conditions cause elevated ROS levels in pancreatic $\beta$-cells $[36,44]$. Therefore, we have examined the role of ROS in $\mathrm{H}_{2} \mathrm{O}_{2}$ - and HGinduced stress conditions (Figures 5(a)(B) and 5(b)(B)). Cells were treated as described above and stained with the redoxsensitive fluorescent probe DCFDA, which was oxidized by intracellular ROS to the highly fluorescent DCF compound detected by the microplate reader. Figures 5(a)(B) and 5(b)(B) show an increase in the production of ROS by 100 units in $100 \mathrm{mM} \mathrm{HG}$, respectively, and by 50 units in $50 \mathrm{mM}$ glucoseinduced stress, compared to the control treatment. CAE 


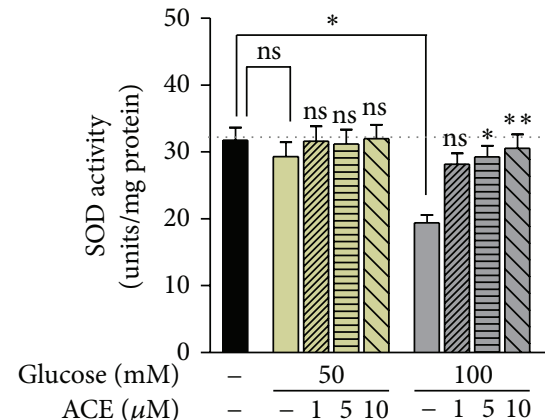

(A)

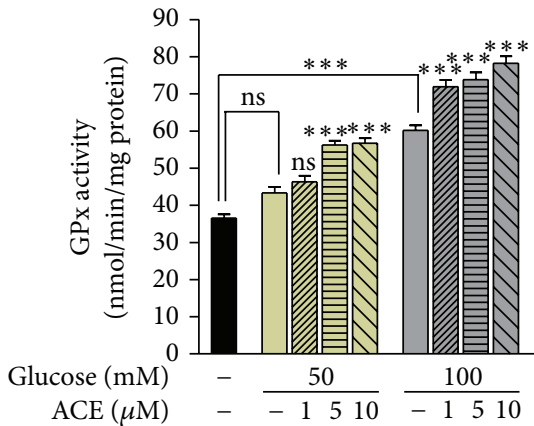

(C)

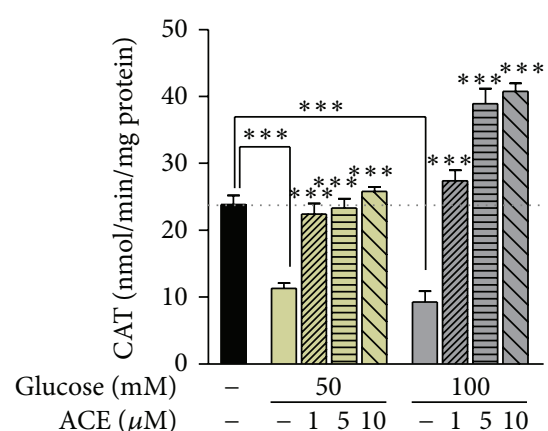

(B)

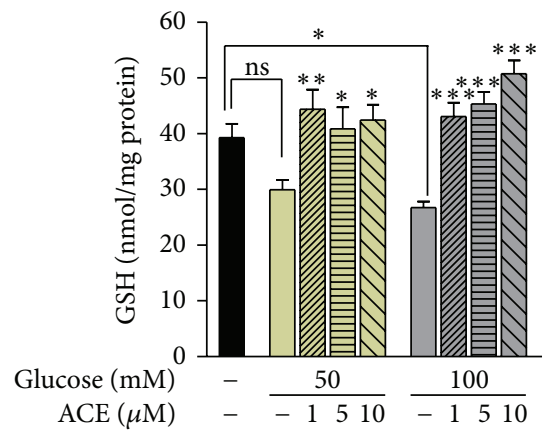

(D)

(a)

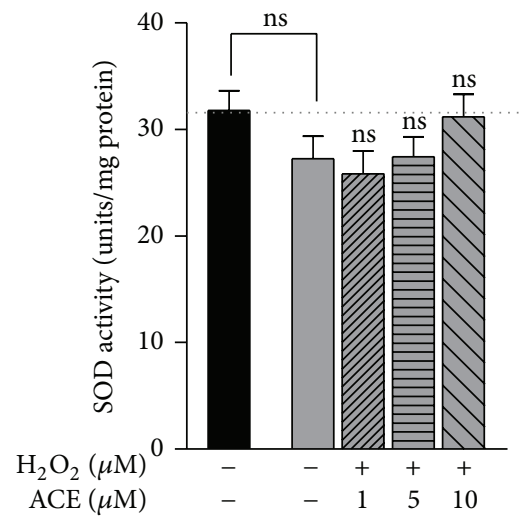

(A)

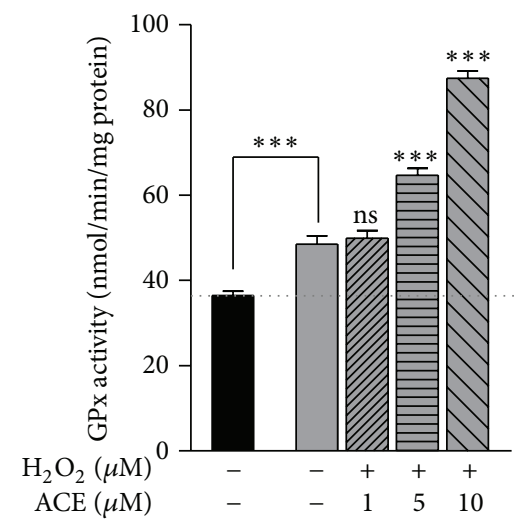

(C)

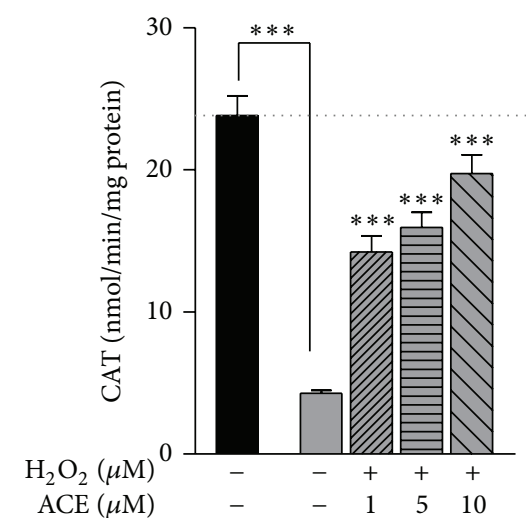

(B)

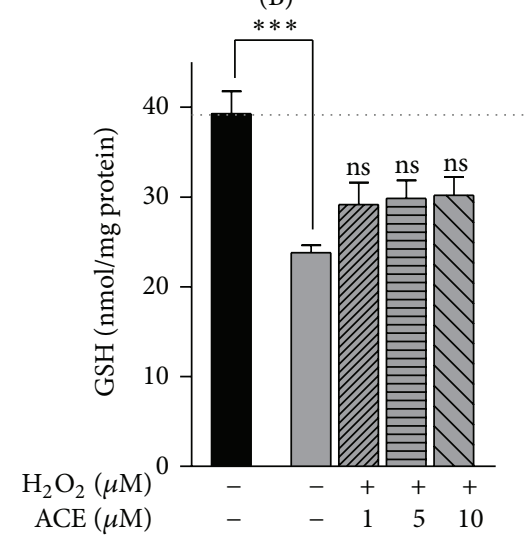

(D)

(b)

FIGURE 4: Effect of CAE on the levels of antioxidant enzyme activities in $\beta$ TC3 cells in stress-induced conditions. (a) HG-induced stress for 24 h: (A) SOD; (B) CAT; (C) GPx; (D) GSH and (b) $\mathrm{H}_{2} \mathrm{O}_{2}$-induced stress for 15 min: (A) SOD; (B) CAT; (C) GPx; (D) GSH. Data are expressed as mean \pm SEM of two independent determinations. Statistical analyses: ${ }^{*} P<0.05$ versus the control. 


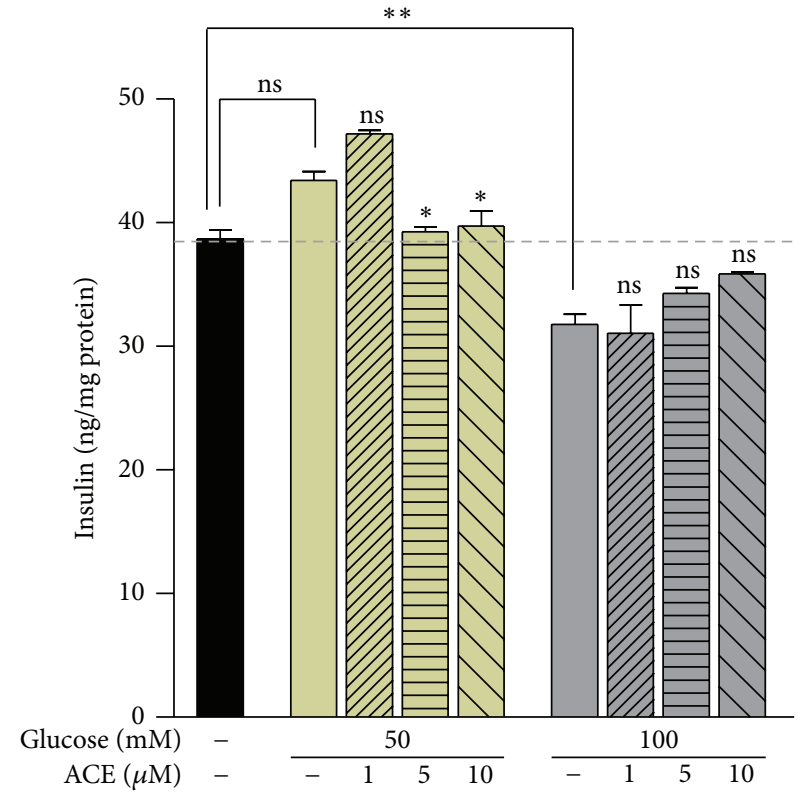

(A)

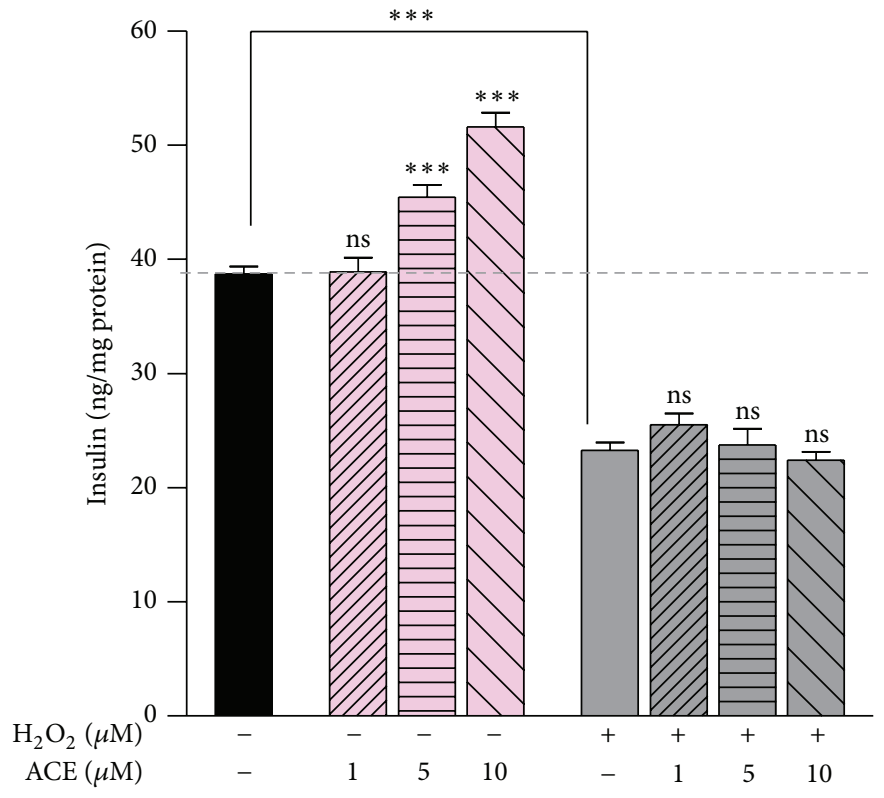

(A)

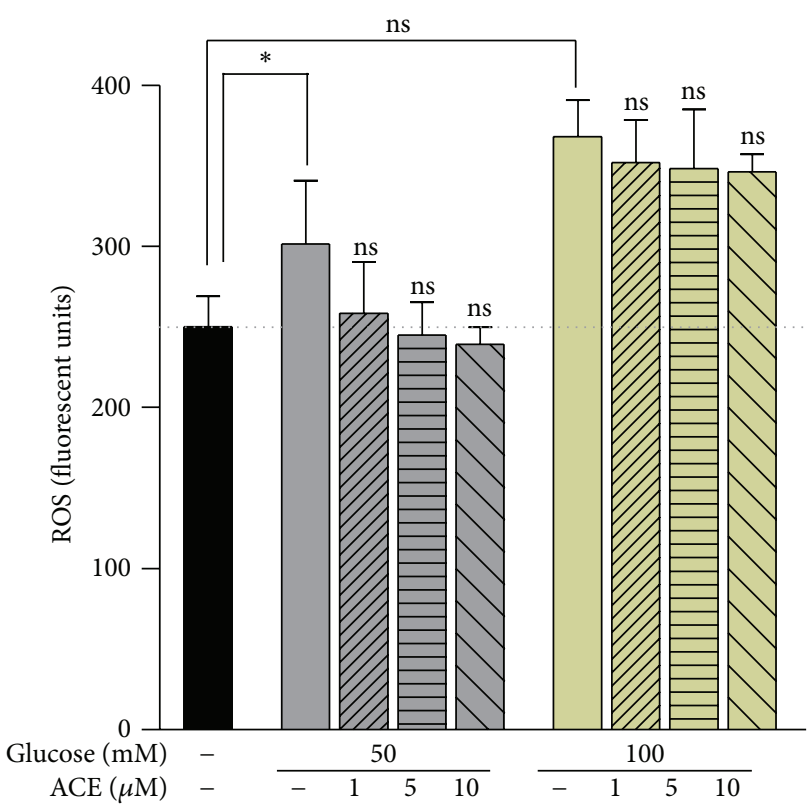

(B)

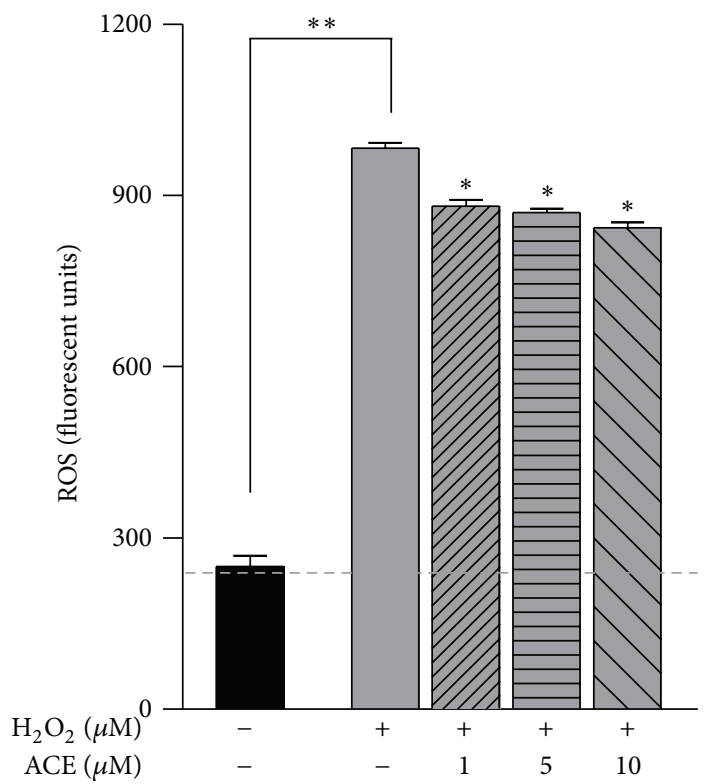

(B)

(b)

FIGURE 5: Effect of CAE on insulin secretion and intracellular reactive oxygen species (ROS) level in $\beta$ TC 3 cells in stress-induced conditions. (a) HG-induced stress for $24 \mathrm{~h}$ and (b) $\mathrm{H}_{2} \mathrm{O}_{2}$-induced stress for $15 \mathrm{~min}$. Data is expressed as mean $\pm \mathrm{SEM}$ of two independent determinations. Statistical analyses: ${ }^{*} P<0.05$ versus the control.

administration attempts to decrease the intracellular ROS level in stress conditions in a dose-dependent manner.

In this study we used hydrogen peroxide- and high glucose-induced toxicity in pancreatic $\beta$-cells as models to evaluate the antioxidant defense system behavior after administration of three physiologically achievable concentrations of chokeberry anthocyanin extract. Furthermore CAE proved to have a role in protecting pancreatic $\beta$-cells increasing the SOD, CAT, GPx, and GSH levels, a secretagogue potential restoring the pool of the insulin, and an antioxidant activity limiting the reactive prooxidants generation in induced stress conditions. In conclusion one can assume a specific role of CAE as a defender of pancreatic $\beta$-cells against the aggressive agents-induced stress conditions, providing 
evidence for the support of the anthocyanins usage as a preventive treatment for diabetes.

\section{Conflict of Interests}

The authors declare that there is no conflict of interests regarding the publication of this paper.

\section{Acknowledgments}

The first author research was supported by European Social Fund Postdoctoral Program POSDRU/89/1.5/S/60746. The authors are also grateful for the financial assistance provided by the Romanian National Authority for Scientific Research, CNCS-UEFISCDI, Project no. PN-II-RU-TE-2011-3-0154.

\section{References}

[1] A. P. Robertson, "Chronic oxidative stress as a central mechanism for glucose toxicity in pancreatic islet beta cells in diabetes," The Journal of Biological Chemistry, vol. 279, no. 41, pp. 42351-42354, 2004.

[2] J. J. Strain, "Disturbances of micronutrient and antioxidant status in diabetes," Proceedings of the Nutrition Society, vol. 50, no. 3, pp. 591-604, 1991.

[3] S. V. McLennan, S. Heffernan, L. Wright et al., "Changes in hepatic glutathione metabolism in diabetes," Diabetes, vol. 40, no. 3, pp. 344-348, 1991.

[4] C. Coman, O. D. Ruginǎ, and C. Socaciu, "Plants and natural compounds with antidiabetic action," Notulae Botanicae Horti Agrobotanici, vol. 40, no. 1, pp. 314-325, 2012.

[5] J. Liu, W. Zhang, H. Jing, and D. G. Popovich, "Bog bilberry (Vaccinium uliginosum 1.) extract reduces cultured Hep-g2, Caco-2, and 3T3-11 cell viability, affects cell cycle progression, and has variable effects on membrane permeability," Journal of Food Science, vol. 75, no. 3, pp. H103-H107, 2010.

[6] B. Zhang, M. Kang, Q. Xie et al., "Anthocyanins from chinese bayberry extract protect $\beta$ cells from oxidative stress-mediated injury via HO-1 upregulation," Journal of Agricultural and Food Chemistry, vol. 59, no. 2, pp. 537-545, 2011.

[7] S. Zafra-Stone, T. Yasmin, M. Bagchi, A. Chatterjee, J. A. Vinson, and D. Bagchi, "Berry anthocyanins as novel antioxidants in human health and disease prevention," Molecular Nutrition \& Food Research, vol. 51, no. 6, pp. 675-683, 2007.

[8] B. Jayaprakasam, S. K. Vareed, L. K. Olson, and M. G. Nair, "Insulin secretion by bioactive anthocyanins and anthocyanidins present in fruits," Journal of Agricultural and Food Chemistry, vol. 53, no. 1, pp. 28-31, 2005.

[9] L. C. Martineau, A. Couture, D. Spoor et al., "Anti-diabetic properties of the Canadian lowbush blueberry Vaccinium angustifolium Ait," Phytomedicine, vol. 13, no. 9-10, pp. 612-623, 2006.

[10] S. Valcheva-Kuzmanova, K. Kuzmanov, V. Mihova, I. Krasnaliev, P. Borisova, and A. Belcheva, "Antihyperlipidemic effect of Aronia melanocarpa fruit juice in rats fed a high-cholesterol diet," Plant Foods for Human Nutrition, vol. 62, no. 1, pp. 19-24, 2007.

[11] A. Jurgoński, J. Juśkiewicz, and Z. Zduńczyk, "Ingestion of black chokeberry fruit extract leads to intestinal and systemic changes in a rat model of prediabetes and hyperlipidemia," Plant Foods for Human Nutrition, vol. 63, no. 4, pp. 176-182, 2008.
[12] C. D. Kay, G. Mazza, and B. J. Holub, "Anthocyanins exist in the circulation primarily as metabolites in adult men," Journal of Nutrition, vol. 135, no. 11, pp. 2582-2588, 2005.

[13] S. Talavéra, C. Felgines, O. Texier et al., "Anthocyanins are efficiently absorbed from the small intestine in rats," Journal of Nutrition, vol. 134, no. 9, pp. 2275-2279, 2004.

[14] C. Manach, G. Williamson, C. Morand, A. Scalbert, and C. Rémésy, "Bioavailability and bioefficacy of polyphenols in humans. I. Review of 97 bioavailability studies," The American Journal of Clinical Nutrition, vol. 81, no. 1, pp. 230S-242S, 2005.

[15] J. He, B. A. Magnuson, G. Lala, Q. Tian, S. J. Schwartz, and M. M. Giusti, "Intact anthocyanins and metabolites in rat urine and plasma after 3 months of anthocyanin supplementation," Nutrition and Cancer, vol. 54, no. 1, pp. 3-12, 2006.

[16] C. D. Kay, G. Mazza, B. J. Holub, and J. Wang, "Anthocyanin metabolites in human urine and serum," British Journal of Nutrition, vol. 91, no. 6, pp. 933-942, 2004.

[17] W. Wiczkowski, E. Romaszko, and M. K. Piskula, "Bioavailability of cyanidin glycosides from natural chokeberry (Aronia melanocarpa) juice with dietary-relevant dose of anthocyanins in humans," Journal of Agricultural and Food Chemistry, vol. 58, no. 23, pp. 12130-12136, 2010.

[18] L. E. Rodriguez-Saona and R. E. Wrolstad, "Extraction, isolation, and purification of anthocyanins," in Current Protocols in Food Analytical Chemistry, John Wiley \& Sons, 2001.

[19] R. Apak, K. Güçlü, M. Özyürek, and S. E. Karademir, "Novel total antioxidant capacity index for dietary polyphenols and vitamins $\mathrm{C}$ and $\mathrm{E}$, using their cupric ion reducing capability in the presence of neocuproine: CUPRAC method," Journal of Agricultural and Food Chemistry, vol. 52, no. 26, pp. 7970-7981, 2004.

[20] M. B. Arnao, A. Cano, J. F. Alcolea, and M. Acosta, "Estimation of free radical-quenching activity of leaf pigment extracts," Phytochemical Analysis, vol. 12, no. 2, pp. 138-143, 2001.

[21] C. P. Lebel, H. Ischiropoulos, and S. C. Bondy, "Evaluation of the probe $2^{\prime}, 7^{\prime}$-dichlorofluorescin as an indicator of reactive oxygen species formation and oxidative stress," Chemical Research in Toxicology, vol. 5, no. 2, pp. 227-231, 1992.

[22] X. Wu, L. Gu, R. L. Prior, and S. McKay, "Characterization of anthocyanins and proanthocyanidins in some cultivars of Ribes, Aronia, and Sambucus and their antioxidant capacity," Journal of Agricultural and Food Chemistry, vol. 52, no. 26, pp. 7846-7856, 2004.

[23] J. Oszmiański and A. Wojdylo, "Aronia melanocarpa phenolics and their antioxidant activity," European Food Research and Technology, vol. 221, no. 6, pp. 809-813, 2005.

[24] D. Rugină, Z. Sconţa, L. Leopold, A. Pintea, A. Bunea, and C. Socaciu, "Antioxidant activities of chokeberry extracts and the cytotoxic action of their anthocyanin fraction on hela human cervical tumor cells," Journal of Medicinal Food, vol. 15, no. 8, pp. 700-706, 2012.

[25] A. Gramza-Michałowska and M. Człapka-Matyasik, "Evaluation of the antiradical potential of fruit and vegetable snacks," ACTA Scientiarum Polonorum Technologia Alimentaria, vol. 10, no. 1, pp. 63-72, 2011.

[26] K. Ogawa, H. Sakakibara, R. Iwata et al., "Anthocyanin composition and antioxidant activity of the crowberry (Empetrum nigrum) and other berries," Journal of Agricultural and Food Chemistry, vol. 56, no. 12, pp. 4457-4462, 2008.

[27] R. Apak, K. Güçlü, B. Demirata et al., "Comparative evaluation of various total antioxidant capacity assays applied to phenolic 
compounds with the CUPRAC assay," Molecules, vol. 12, no. 7, pp. 1496-1547, 2007.

[28] E. Sariburun, S. Şahin, C. Demir, C. Türkben, and V. Uylaşer, "Phenolic content and antioxidant activity of raspberry and blackberry cultivars," Journal of Food Science, vol. 75, no. 4, pp. C328-C335, 2010.

[29] J. M. Choi, B. S. Yoon, S. K. Lee, J. K. Hwang, and R. Ryang, "Antioxidant properties of neohesperidin dihydrochalcone: Inhibition of hypochlorous acid-induced DNA strand breakage, protein degradation, and cell death," Biological and Pharmaceutical Bulletin, vol. 30, no. 2, pp. 324-330, 2007.

[30] S. Lee, I. S. Ha, J. H. Kim et al., "Hydrogen peroxide-induced VCAM-1 expression in pancreatic islets and $\beta$-Cells through extracellular Ca2+ influx," Transplantation, vol. 86, no. 9, pp. 1257-1266, 2008.

[31] E. Rebelato, F. Abdulkader, R. Curi, and A. R. Carpinelli, "Control of the intracellular redox state by glucose participates in the insulin secretion mechanism," PLoS ONE, vol. 6, no. 8, Article ID e24507, 2011.

[32] K. C. Won, J. S. Moon, M. J. Eun et al., "A protective role for heme oxygenase-1 in INS-1 cells and rat islets that are exposed to high glucose conditions," Journal of Korean Medical Science, vol. 21, no. 3, pp. 418-424, 2006.

[33] C. González, M. Andrews, E. Leiva, C. Quispe, and M. Arredondo, "Antioxidant effects of alperujo extract (Arbequina and Frantoio varieties) on MIN6 $\beta$-cells subjected to stress with glucose or $\mathrm{H}_{2} \mathrm{O}_{2}$," Food and Nutrition Sciences, vol. 5, no. 13, pp. 1280-1289, 2014.

[34] J. Liu, M. M. Hinkhouse, W. Sun et al., "Redox regulation of pancreatic cancer cell growth: role of glutathione peroxidase in the suppression of the malignant phenotype," Human Gene Therapy, vol. 15, no. 3, pp. 239-250, 2004.

[35] M. Tiedge, S. Lortz, R. Munday, and S. Lenzen, "Protection against the co-operative toxicity of nitric oxide and oxygen free radicals by overexpression of antioxidant enzymes in bioengineered insulin-producing RINm5F cells," Diabetologia, vol. 42, no. 7, pp. 849-855, 1999.

[36] R. P. Robertson, J. Harmon, P. O. Tran, Y. Tanaka, and H. Takahashi, "Glucose toxicity in $\beta$-cells: type 2 diabetes, good radicals gone bad, and the glutathione connection," Diabetes, vol. 52, no. 3, pp. 581-587, 2003.

[37] P. Ježek, A. Dlasková, and L. Plecitá-Hlavatá, "Redox homeostasis in pancreatic $\beta$ cells," Oxidative Medicine and Cellular Longevity, vol. 2012, Article ID 932838, 16 pages, 2012.

[38] M. Roy, S. Sen, and A. S. Chakraborti, "Action of pelargonidin on hyperglycemia and oxidative damage in diabetic rats: implication for glycation-induced hemoglobin modification," Life Sciences, vol. 82, no. 21-22, pp. 1102-1110, 2008.

[39] M. Kajikawa, S. Fujimoto, Y. Tsuura et al., "Ouabain suppresses glucose-induced mitochondrial ATP production and insulin release by generating reactive oxygen species in pancreatic islets," Diabetes, vol. 51, no. 8, pp. 2522-2529, 2002.

[40] K. Sakai, K. Matsumoto, T. Nishikawa et al., "Mitochondrial reactive oxygen species reduce insulin secretion by pancreatic $\beta$-cells," Biochemical and Biophysical Research Communications, vol. 300, no. 1, pp. 216-222, 2003.

[41] Y. Kajimoto and H. Kaneto, "Role of oxidative stress in pancreatic $\beta$-cell dysfunction," Annals of the New York Academy of Sciences, vol. 1011, pp. 168-176, 2004.
[42] H. Guo, W. Ling, Q. Wang et al., "Effect of anthocyanin-rich extract from black rice (Oryza sativa L. indica) on hyperlipidemia and insulin resistance in fructose-fed rats," Plant Foods for Human Nutrition, vol. 62, no. 1, pp. 1-6, 2007.

[43] R. Sasaki, N. Nishimura, H. Hoshino et al., "Cyanidin 3glucoside ameliorates hyperglycemia and insulin sensitivity due to downregulation of retinol binding protein 4 expression in diabetic mice," Biochemical Pharmacology, vol. 74, no. 11, pp. 1619-1627, 2007.

[44] E. Rebelato, F. Abdulkader, R. Curi, and A. R. Carpinelli, "Low doses of hydrogen peroxide impair glucose-stimulated insulin secretion via inhibition of glucose metabolism and intracellular calcium oscillations," Metabolism, vol. 59, no. 3, pp. 409-413, 2010. 


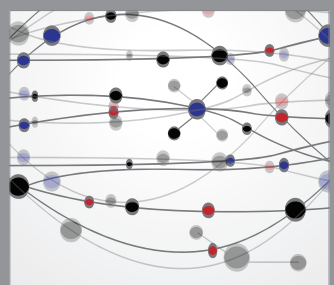

The Scientific World Journal
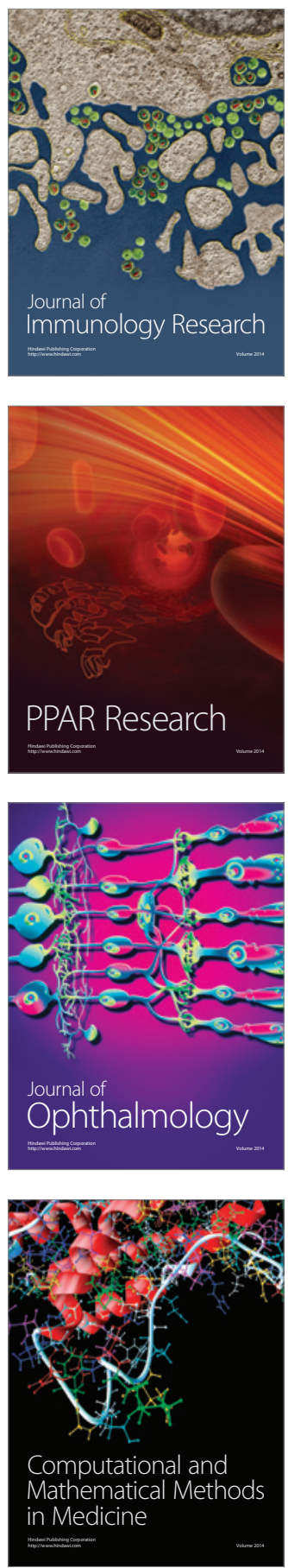

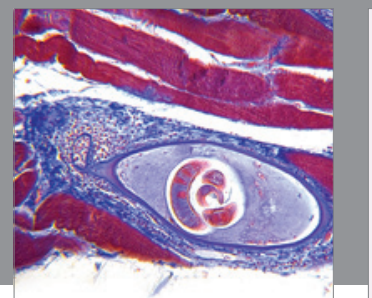

Gastroenterology

Research and Practice
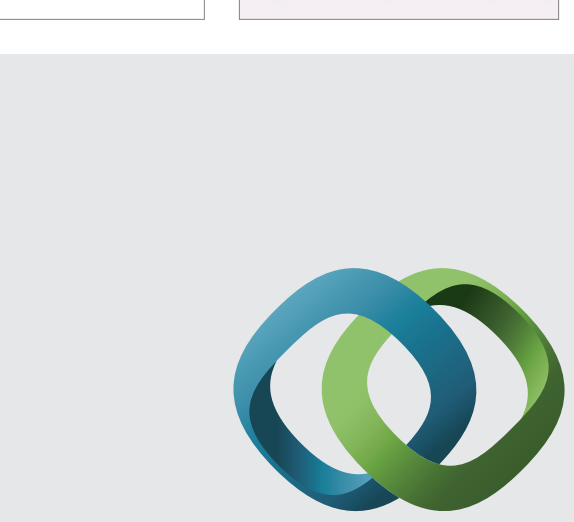

\section{Hindawi}

Submit your manuscripts at

http://www.hindawi.com
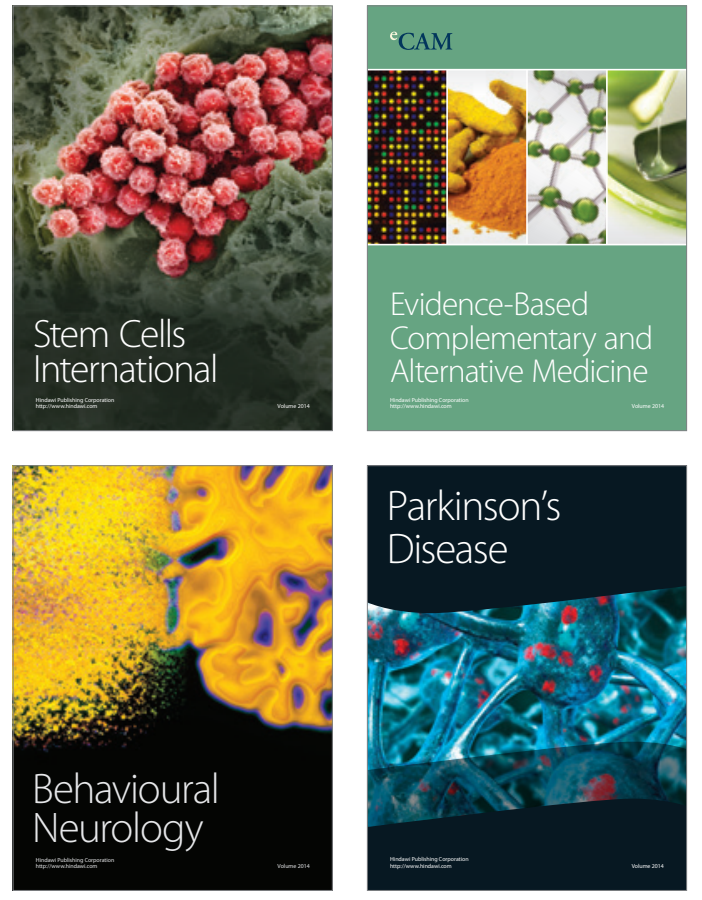
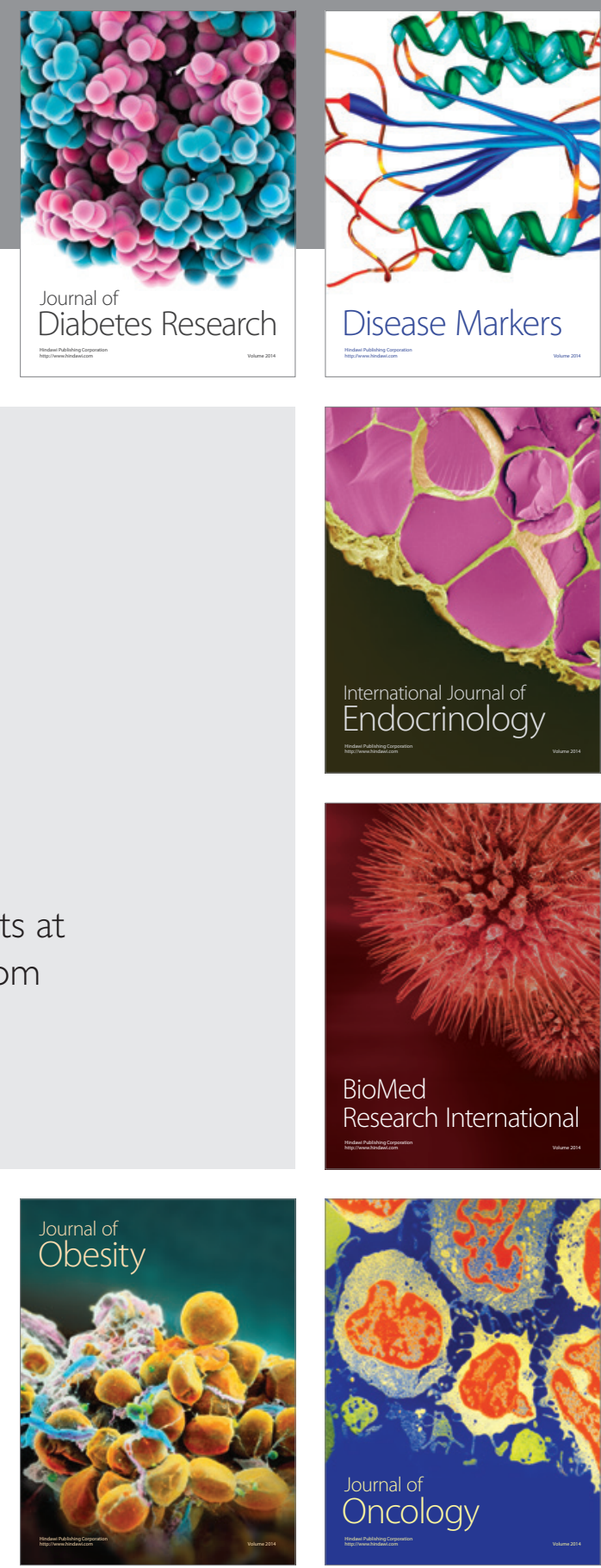

Disease Markers
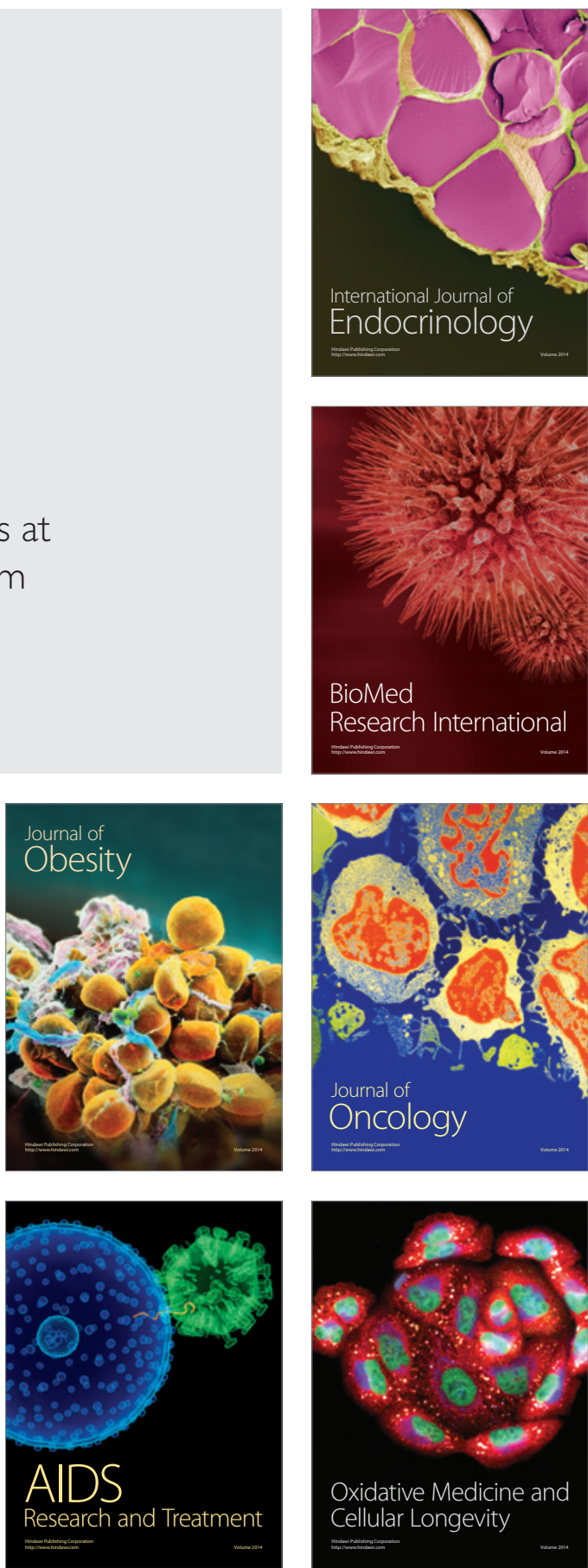